\title{
What to Aim for? The Choice of an Inflation Objective when Openness Matters
}

February $26^{\text {th }}, 2015$

Richard T. Froyen

Department of Economics

University of North Carolina

Chapel Hill, NC 27599-3305

USA

\author{
Alfred V. Guender \\ Department of Economics and Finance \\ University of Canterbury \\ Christchurch \\ New Zealand
}

Key Words: CPI, Domestic, REX Inflation Targeting, Discretion, Timeless Perspective.

JEL Code: E3, E5, F3

\begin{abstract}
:
Inflation targeting countries generally define the inflation objective in terms of the consumer price index. Studies in the academic literature, however, reach conflicting conclusions concerning which measure of inflation a central bank should target in a small open economy. This paper examines the properties of domestic, CPI, and real-exchange- rate-adjusted (REX) inflation targeting. In one class of open economy New Keynesian models there is an isomorphism between optimal monetary policy in an open versus closed economy. In the type of model we consider, where the real exchange rate appears in the Phillips curve, this isomorphism breaks down; openness matters. REX inflation targeting restores the isomorphism but this may not be desirable. Instead, under domestic and CPI inflation targeting the exchange rate channel can be exploited to enhance the effects of monetary policy. Our results indicate that CPI inflation targeting can deliver price stability across the three inflation objectives and will be desirable to a central bank with a high aversion to inflation instability. REX inflation targeting does well in delivering output stability and has a relative advantage in economies where demand shocks are predominant. In general, the choice of the inflation objective affects the trade-offs between policy goals and thus policy choices and outcomes.
\end{abstract}

E-mail: froyen@email.unc.edu; Alfred.Guender@ canterbury.ac.nz 
Inflation targeting requires the choice of a specific inflation objective. Countries that have adopted inflation targeting define the objective in terms of the consumer price index [Svensson (2011)]. This choice is not surprising as inflation targeting countries tend to be small open economies where import inflation is a concern. Performance is typically measured by the central bank's ability to keep annual or mean CPI inflation within a target band or close to a numerical target. ${ }^{1,2}$

The academic literature on monetary policy acknowledges that the choice of which measure of inflation to target is important (Woodford (2011)). Existing studies, however, reach conflicting conclusions about a central bank's appropriate target criterion for inflation in a small open economy. Allsopp, Kara, and Nelson (2006) favor CPI inflation targeting in a New Keynesian model where exchange rate changes act like supply shocks. In contrast, a number of influential contributions to the New Keynesian literature (Aoki (2001), Clarida, Gali, and Gertler (1999, 2001, 2002), Gali and Monacelli (2005), Kirsanova, Leith, and Wren-Lewis (KLWL) (2006), De Paoli (2009) and others) advocate the stabilization of domestic rather than CPI inflation. The focus on domestic inflation as a central bank's inflation objective is dictated by microeconomic considerations. The central bank's objective function is derived explicitly from welfare analysis which maximizes the utility of the representative consumer. ${ }^{3,4}$

Models such as Clarida, Gali, and Gertler (1999, 2001, 2002) and Gali and Monacelli (2005) have the stronger implication that optimal policy in an open economy is isomorphic to policy in a closed economy. This view is reflected in a target rule in an open economy which is the same as in a closed economy except that the weight on domestic inflation is now affected by the degree of openness. This isomorphism is a distinctive feature of models where the output gap is the sole conduit through which monetary policy affects the Phillips curve.

The isomorphism result in an open economy New Keynesian framework has not gone unchallenged. KLWL (2006) add a terms of trade gap to the objective function of the central bank after allowing for a wider range of plausible values for the intertemporal elasticity of

1 For a recent survey, see Walsh (2009).

2 A few central banks focus on headline CPI inflation while others monitor the behavior of core inflation, a measure of inflation excluding food and energy price changes.

3 The welfare-based loss function is model-dependent, includes an output and domestic inflation objective and may feature other target variables such as the terms of trade or the real exchange rate.

4 The endogenous loss function becomes more complex even in closed-economy models which feature additional inputs such as energy (Bodenstein, Erceg, and Guerrieri (2008)). While the energy input allows for distinguishing between core and headline inflation, the key feature of the canonical closed-economy New Keynesian model - the target rule being dependent solely on the objective function and the supply block of the model - remains intact. 
consumption and the elasticity of demand. Altering the objective function of the central bank breaks the isomorphism result. Exchange rate related frictions and an imported input in production also result in the failure of the isomorphism result. Monacelli (2005) describes how incomplete-exchange rate pass-through alters the Phillips curve in an open economy. Domestic inflation is affected by the wedge between the world price (in domestic currency) and the home currency price set by importers of the consumption good. In Monacelli (2013) the existence of an imported intermediate input in production calls for both real marginal cost (the inverse of the mark-up) and the terms of trade to be variable. ${ }^{5}$ Corsetti, Dedola and Leduc (2011), Engel (2010), Benigno and Benigno (2006), and Clarida, Gali and Gertler (2002) analyze target rules in a two-country framework where the definition of the central bank's objective function depends on factors such as: the values of deep parameters, local versus producer currency pricing, and cooperative versus non-cooperative policymakers. ${ }^{6}$

This paper examines the implications of a central bank's choice of a specific inflation objective within a flexible inflation targeting strategy. We show that the breakdown or survival of the isomorphism result hinges critically on the choice of the inflation objective in the central bank's targeting strategy. Practical considerations matter: the measure of inflation the central bank aims at is crucial in determining whether optimal policy in the open economy is fundamentally different from optimal monetary policy in its closed economy counterpart. The choice of the inflation objective affects the form of the optimal target rule and thus trade-offs between policy goals that confront the policymaker

Our analysis is conducted within a model with a foundation for an exchange rate channel in the Phillips curve which does not rely on a particular currency misalignment such as incomplete exchange rate pass-through or on imports of intermediate inputs. Our Phillips curve is derived from a setting where domestic firms produce goods for the home market and exports. Its theoretical basis is grounded in an optimizing framework where domestic firms are concerned, amongst other things, about their competitiveness vis-à-vis foreign firms. As a result, prices set by domestic firms respond to exchange rate fluctuations and changes in the prices charged by competing foreign firms. Such pricing behavior in small open economies is

\footnotetext{
5 Monacelli (2013) argues that consumption openness (under perfect exchange rate pass-through) also accounts for the breakdown of the isomorphism result.

6 Using a symmetric two-country framework, Bodenstein, Guerrieri, and Kilian (2012) analyze optimal interest rate responses to headline versus core inflation with endogenous energy prices. Their analysis focuses on optimal and simple instrument rules.
} 
confirmed by recent survey evidence compiled by Greenslade and Parker (2012) for the United Kingdom and Parker for New Zealand (2013). ${ }^{7}$

If, at the firm level, the pricing of output is sensitive to movements in the exchange rate and competitive price pressure from abroad, then, at the aggregate level, such pricing behavior results in a Phillips curve which features a direct real exchange rate channel. The standard inflation expectations and the output gap channels are thus complemented by this real exchange rate channel. Following Ball (1999) and Svensson (2000), we trace the implications for monetary policy of the existence of a real exchange rate channel in the Phillips curve, albeit in a different modeling framework. ${ }^{8}$

Our analysis begins with a central bank that adopts a strategy of flexible inflation targeting. To be operational, a flexible inflation targeting strategy must specify a specific inflation measure along with any other objectives. We examine three flexible inflation targeting strategies: domestic inflation targeting, CPI inflation targeting, and real-exchange rate-adjusted (REX) inflation targeting. REX inflation is defined as domestic inflation purged of the effects of real exchange rate changes. ${ }^{9}$ For each of these strategies we derive the optimal target rule and analyze the ways in which the rule differs from the rule in the canonical closed-economy New Keynesian model.

For CPI or domestic inflation targeting, our analysis leads to several conclusions. First, the real exchange rate plays a much more important role in the design of target rules than in most previous frameworks. ${ }^{10}$ Second, the isomorphism result in the earlier literature breaks down if there is a separate exchange rate channel in the Phillips curve. In particular, demandside shocks cannot be offset without affecting inflation through the Phillips curve. Third, the exchange rate channel for policy improves the inflation- output tradeoff in the presence of cost-push shocks. As a consequence of this improved trade-off, more weight is put on inflation stabilization in the target rule. Fourth, the gains to commitment under the timeless perspective are diminished.

\footnotetext{
7 In New Zealand, competitors' price changes - both increases and decreases - were deemed to be the most important factor in an exporting firm's decision to change price. Exchange rate changes were found to be an important or very important factor in determining price changes by more than 70 percent of exporters among the survey respondents in the United Kingdom. Support for the importance of exchange rates changes as a factor influencing price setting in the United Kingdom is also provided by Bunn and Ellis (2012a, 2012b).

8 Ball's model is completely backward-looking while Svensson's features both backward-and forward-looking elements.

9 Similar to Ball's (1999) definition of long-run inflation. However, his definition involves the level and not the change of the real exchange rate.

10 Engel (2010) comes to the same conclusion albeit in a two-country framework with local currency pricing and risk sharing.
} 
REX inflation targeting restores the isomorphism with policy in the closed economy. It becomes more desirable as the consequences of openness just set out become undesirable. As the incidence of demand-side shocks increases relative to cost push shocks, for example, the ease with which these shocks are offset in the closed economy favors REX inflation targeting. REX inflation targeting also becomes more desirable if the central bank puts more weight on output stabilization in the objective function; openness, by improving the inflationoutput-trade-off, raises the opportunity cost of gains in output stability.

A central bank's innate aversion to inflation relative to output variability plays a decisive role in the choice of which inflation rate to target. Even if demand-side shocks are substantially more volatile than cost-push shocks, an optimizing central bank that places greater emphasis on price stability chooses CPI inflation targeting over domestic or REX inflation targeting. One attractive feature of CPI inflation targeting is that it also ensures stability of domestic and REX inflation while the reverse does not hold.

The remainder of the paper is organized as follows. In Section 2 we derive an openeconomy Phillips curve and incorporate it into a small open-economy New Keynesian model. Section 3 discusses the three flexible inflation targeting strategies. A performance analysis is carried out and commented on in Section 4. Section 5 compares policy under discretion to policy with commitment from a timeless perspective. Section 6 concludes.

\section{The Building Blocks of the Model}

\section{A. An Open Economy Phillips Curve}

The central building block for our open economy Phillips curve is the firm's pricing equation. Recent evidence from surveys [Greenslade and Parker (2012) and Parker (2012)] as well as from micro data [Bunn and Ellis (2012a), (2012b)] indicate wide divergence in pricing behavior within and across sectors of the economy. These studies cast doubt on whether any one theory of price setting can adequately capture all the important features of firm pricing. In particular the popular specification of Calvo (1983) pricing supplemented by "rule of thumb" indexation appears to describe actual pricing behavior of only a small minority of firms. Given the heterogeneity of firm pricing behavior, any aggregate price setting equation will be an approximation aimed at capturing some central features of the process.

The pricing framework here emphasizes three elements, each of which receives support from surveys. First, we assume firms follow mark-up pricing influenced by the benchmark prices of competing domestic firms. Second, we assume that there is price stickiness due to 
menu costs. Menu costs include not just the physical costs of price changes but are also the result of implicit and explicit contracts as well as coordination problems.

Finally, in the open economy the firm needs to be concerned with competitiveness at home and abroad. Thus the firm responds to exchange rate induced changes in the terms of trade. This concern is highlighted by recent articles in the financial press citing the cost of sudden currency movements and the way in which domestic producers in small open economies react to exchange rate volatility:

"Companies plan a year to 18 months ahead. If there are very strong currency movements, companies don't have time to react and hedge."

"More important than the absolute level is the amount of [exchange rate] volatility you see and how fast these swings are happening. Last year the swings were a little too fast for what a normal company is set up to adjust to. ",11

"As an exporter, the way we defend on exchange rate variance is by putting prices up or down."

“We've put our prices up several times, and now we are bringing them down, so that makes for an unstable pricing policy and makes our products hard to sell. ,"12

We model these elements of optimal price setting within an extension of Rotemberg's (1982) quadratic cost adjustment model of monopolistically competitive firms. In our openeconomy version of the model an optimizing firm sets the price of output so that the overall cost function which consists of three separate components is minimized. The objective function of the typical firm $j$ is:

$$
\min _{p(j)_{t}} \Omega(j)_{t}=E_{t} \sum_{i=0}^{\infty} \beta^{i}\left[\begin{array}{c}
\left(p(j)_{t+i}-p(j)_{t+i}^{*}\right)^{2}+c\left(p(j)_{t+i}-p(j)_{t+i-1}\right)^{2}+ \\
a\left(q(j)_{t+i}-q(j)_{t+i-1}\right)^{2}
\end{array}\right]
$$

where:

$\Omega(j)_{t}=$ the total cost of firm $j$ at time $t$

$p(j)_{t}=$ the price of the good produced by firm $j$ at time $t$

$p(j)_{t}^{*}=$ the optimal mark-up price for firm $j$

$q(j)_{t}=p_{t}^{f}+s_{t}-p(j)_{t}=$ firm-specific terms of trade

$\beta=$ the constant discount factor

11 New York Times, March 17, 2010.

12 Christchurch Press, New Zealand, October $5^{\text {th }}, 2011$. 
$c=$ the parameter that measures the costs of changing prices relative to the costs of deviating from the optimal mark-up price

$a=$ the parameter that measures the costs of changes in the firm's terms of trade relative to the costs of deviating from the optimal mark-up price

$E_{t}=$ the expectations operator conditional on information available at time $t$.

The first term within the brackets is the cost of being away from the optimal mark-up on cost, the price that the firm would charge in the absence of menu costs and foreign competition. This price, the specification of which is explained below, is denoted $p(j)^{*}$. Menu costs are represented by the second term in brackets.

In an open economy, as explained previously, firms are concerned about competitiveness abroad as well as at home. Define the terms of trade (or real exchange rate) as the domestic currency price of foreign output relative to the price of domestic output. The firm-specific terms of trade measure a representative firm's price competitiveness vis-à-vis foreign competition. Changes in its terms of trade make it difficult for the firm to maintain its presence in established markets abroad and interfere with laying out roadmaps (product design, export strategies) for the future. To avoid changes in its terms of trade caused by sudden exchange rate movements or foreign price movements both of which are beyond its control, the firm is required to alter its price. Menu costs make this costly.

The firm sets the price of its output in domestic currency. Taking the first-order condition and running the expectations operator through it, we can characterize the relationship between past, current, and future prices as well as the current and expected change in the terms of trade as: ${ }^{13}$

$p(j)_{t}-p(j)_{t-1}=\beta E_{t}\left(p(j)_{t+1}-p(j)_{t}\right)-\frac{1}{c}\left(p(j)_{t}-p(j)_{t}^{*}\right)-\frac{\beta a}{c}\left(E_{t} q(j)_{t+1}-q(j)_{t}\right)+$ $\frac{a}{c}\left(q(j)_{t}-q(j)_{t-1}\right)$

From equation (2) it is evident that the current and the expected change in the firm-specific terms of trade matter in setting the price at time $t$. The greater $a$ - the relative weight on the change in the terms of trade in the total cost function - compared to $c$, the relative weight on costly price changes, the more current and expected changes in the terms of trade factor in the decision to change the price in the current period. As stated above, changes in the current nominal exchange rate and changes in the price charged by competing foreign firms are

13 From the definition of the firm-specific terms of trade and the fact that the firm cannot influence the price set by foreign competitors or the nominal exchange rate it follows that $\frac{\partial q(j)_{t}}{\partial p(j)_{t}}=-1$. 
exogenous to the firm. Yet such changes affect a domestic firm's terms of trade, i.e. its competitiveness. The only way that a domestic firm can counteract such pressure is to adjust its domestic price in such a way so that overall costs are minimized.

Next, consider the formation of the firm's optimal mark-up price:

$p(j)_{t}^{*}=\widehat{p_{t}}+\vartheta y(j)_{t}+\varsigma(j)_{t} \quad \varsigma>0$

where all variables are as previously defined. In addition:

$\hat{p}_{t}=$ the price charged by competing firms at time $t$

$y(j)_{t}=$ output produced (relative to potential) by firm $j$

$\varsigma(j)_{t}=$ a stochastic disturbance.

Under imperfect competition, $p(j)_{t}^{*}$ is a mark-up over marginal cost. But marginal cost and real output are positively related. ${ }^{14}$ Therefore we replace marginal cost with the output gap in (3). To capture the idea of a time-varying mark-up factor, we model it as a random element $s(j)_{t}$ that enters into the process of setting the optimal mark-up price. ${ }^{15}$ The other important factor that influences the firm's optimal mark-up price is the benchmark price set by competing firms. This price, denoted by $\hat{p}_{t}$, equals the aggregate domestic price level $p_{t}$.

Substituting equation (3) into (2) and aggregating over all firms yields equation (4), an open-economy Phillips curve where, in addition to the output gap and expected domestic inflation, the current and expected change in the real exchange rate affect current domestic inflation. ${ }^{16}$

$$
\pi_{t}=\beta E_{t} \pi_{t+1}+\kappa y_{t}+b\left(q_{t}-q_{t-1}\right)-\beta b\left(E_{t} q_{t+1}-q_{t}\right)+u_{t}
$$

where

$$
\begin{aligned}
& \pi_{t}=p_{t}-p_{t-1} \quad q_{t}=p_{t}^{f}+s_{t}-p_{t} \\
& \kappa=\frac{\vartheta}{c} \quad b=\frac{a}{c} \quad u_{t}=\frac{1}{c} \varsigma_{t} .
\end{aligned}
$$

14 Equation (3) is the same as the one proposed by Roberts (1995). Within a general equilibrium framework, the co-movement between marginal cost and economic activity can be established by combining the labor supply and demand relations with the market clearing condition in the goods market. On this point see Clarida, Gali, and Gertler (2001, 2002) or Gali and Monacelli (2005) who derive a similar relation that stresses the positive relation between real marginal cost and domestic consumption.

15 For an investigation of the time-varying mark-up factor, see Ball and Romer (2003).

16 For simplicity there is no distinction between the terms of trade and the real exchange rate. 
Compared to the standard closed-economy Phillips curve, the open-economy representation features a more expansive expectations channel that operates through expected changes in the real exchange rate. In addition, the current period change in the real exchange rate exerts a direct effect on domestic inflation. Thus, in the open-economy framework described below the transmission mechanism of monetary policy is not solely through the output gap.

\section{B. Model for a Small Open Economy}

The complete model for a small open economy consists of four equations:

$$
\begin{aligned}
& \pi_{t}=\beta E_{t} \pi_{t+1}+\kappa y_{t}+b\left(q_{t}-q_{t-1}\right)-\beta b\left(E_{t} q_{t+1}-q_{t}\right)+u_{t} \\
& y_{t}=E_{t} y_{t+1}-a_{1}\left(R_{t}-E_{t} \pi_{t+1}^{C P I}\right)+a_{2}\left(q_{t}-E_{t} q_{t+1}\right)+a_{3}\left(y_{t}^{f}-E_{t} y_{t+1}^{f}\right)+v_{t} \\
& \quad R_{t}-E_{t} \pi_{t+1}=R_{t}^{f}-E_{t} \pi_{t+1}^{f}+E_{t} q_{t+1}-q_{t}+\varepsilon_{t} \\
& \pi_{t}^{C P I}=\pi_{t}+\gamma \Delta q_{t}
\end{aligned}
$$

$\pi_{t}=$ the rate of domestic inflation

$E_{t} \pi_{t+1}^{C P I}=$ the expected rate of CPI inflation

$q_{t}=$ the real exchange rate

$y_{t}=$ the output gap

$R_{t}=$ the nominal rate of interest (policy instrument)

$R_{t}^{f}=$ the foreign nominal rate of interest

$E_{t} \pi_{t+1}^{f}=$ the expected foreign rate of inflation

$y_{t}^{f}=$ the foreign output gap

Lower case variables represent logarithms. All parameters are positive. The discount factor $\beta$ is less than or equal to one.

Equation (4) is the open-economy Phillips curve. Equation (5) is the open economy IS relation that features a real interest rate and real exchange rate channel. A foreign output shock and an idiosyncratic shock affect demand for domestic output. ${ }^{17}$ Equation (6) is the linearized uncovered interest rate parity (UIP) condition: apart from a stochastic risk

17 The derivation of the forward-looking IS relation from microeconomic foundations is explained in Guender (2006). A separate appendix, available from the authors, shows how the shocks that appear in the IS relation can be motivated. 
premium $\left(\varepsilon_{t}\right)$ agents are assumed to trade in a frictionless international bond market. More formally, the stochastic disturbances are modeled as follows: ${ }^{18}$

$$
\begin{array}{lll}
u_{t} \sim N\left(0, \sigma_{u}^{2}\right) & v_{t} \sim N\left(0, \sigma_{v}^{2}\right) & \varepsilon_{t} \sim N\left(0, \sigma_{\epsilon}^{2}\right) \\
R_{t}^{f} \sim N\left(0, \sigma_{R}^{2}\right) & \pi_{t}^{f} \sim N\left(0, \sigma_{\pi^{f}}^{2}\right) & y_{t}^{f} \sim N\left(0, \sigma_{y^{f}}^{2}\right)
\end{array}
$$

We treat all foreign variables as exogenous random variables that are independent of each other. Finally, equation (7) describes the relationship between the CPI inflation rate, the domestic inflation rate, the real exchange rate, and consumption openness $(\gamma)$ under perfect exchange rate pass-through.

\section{Targeting Different Measures of Inflation: Optimal Monetary Policy under Discretion}

Woodford (2011, p.802) recognizes that "the question as to which measure of inflation should be targeted by a central bank is an important practical question for the theory of monetary policy." In the context of an open economy what criteria should guide this choice and, more generally, that of an inflation targeting regime? The literature distinguishes two approaches. One emphasizes a welfare theoretic approach to determine the central bank's target criterion while the other is a "simple representation of conventional central bank objectives (Woodford (2011, p.728)." Under the welfare-theoretic target criterion, the central bank generally minimizes a loss (objective) function given by an approximation to a representative household's utility function. The loss function is model-specific and depends critically on the specification of the consumer's utility function and the values chosen for the elasticity of substitution, elasticity of demand, the extent of exchange rate pass-through, and other factors. ${ }^{19,20}$ Moreover, as Woodford (2011, p.776) concludes "in a broad range of models" maximizing the expected utility of a representative household is consistent with a central bank's objective of minimizing fluctuations in some measure of inflation and the output gap. ${ }^{21}$ Thus the welfare theoretic approach and the more pragmatic representation of

\footnotetext{
18 The property that all shocks are white noise follows Woodford (1999a). Its purpose is to show that gradual adjustment of the output gap, the rate of inflation, etc. and the policy instrument under policy from a timeless perspective is not exclusively tied to the presence of autocorrelated disturbances in the model. 19 Kirsanova et al (2006) show that relaxing the assumptions of unitary elasticity of demand and intertemporal substitution results in a far more complex welfare criterion than proposed by Gali and Monacelli (2005).

20 Clarida, Gali and Gertler (1999, p.1688) conclude that the micro-founded DSGE New Keynesian approach "could be misleading as a guide to welfare analysis because of its highly stylized microeconomic underpinnings." Sims (2012) echoes their concerns citing the implausibility of the microeconomic foundations of these DSGE models.

21 Woodford (2011, p.822) emphasizes this point in his survey article. He states that "[a]s a practical matter, then, it is important to formulate recommendations for relatively simple target criteria, that, while not expected to be fully optimal, it is nonetheless an approximate optimal policy to a reasonable extent."
} 
conventional central bank objectives are broadly consistent in many contexts. Here we assume that the central bank decides on (or is assigned) a menu of possible flexible inflation targets. Using a small open economy New Keynesian framework featuring standard real interest and exchange rate channels, the central bank traces out the implications of adopting alternative inflation targets to assess their relative performance.

In the following sections we consider three different targeting regimes. A targeting regime is characterized by the target variables that appear in the objective function of the central bank. A flexible inflation targeting regime is one where the central bank is concerned about variables other than just the rate of inflation. In the simple version used here flexible inflation targeting is where the objective function consists of squared deviations of the output gap and the particular rate of inflation the central bank targets. ${ }^{22}$ Three possible inflation targets are: domestic inflation, exchange-rate adjusted inflation, and CPI inflation. At the core of each inflation targeting regime is an optimal target rule that prescribes how the target variables proper and relevant endogenous variables interact to ensure that the objective function is minimized.

\section{A. Targeting Domestic Inflation}

In the first strategy we consider, the rate of inflation is defined in terms of changes in the level of domestic prices. The explicit objective function that the central bank attempts to minimize is given by:

$$
E_{t} \sum_{i=0}^{\infty} \beta^{i}\left[y_{t+i}^{2}+\mu \pi_{t+i}^{2}\right]
$$

$\beta$ is the discount rate and $\mu$ represents the relative weight the policymaker attaches to the squared deviations of the rate of domestic inflation from target. Equation (8) implies that the policymaker's sole concern rests with the output gap and domestic inflation. ${ }^{23}$

To set the stage for illustrating how optimal policy in the open economy is determined, it is helpful at the outset to reduce the dimension of the optimization problem to one involving only two constraints. Two simple steps need to be taken. First, substitute for the rate of CPI inflation in equation (5). Second, substitute the UIP condition into the IS equation. The optimization problem can then be expressed as:

22 The mandate for central banks is often restricted to ensuring price and output stability. In countries like New Zealand the overriding goal of monetary policy is to guarantee price stability without causing undue fluctuations in the real economy, interest rates, and the exchange rate. Thus variables other than the rate of inflation and the output gap could appear in the central bank's objective function. Indeed, Blanchard et al (2010, p. 210) argue that "[c]entral banks in small open economies should openly recognize that exchange rate stability is part of their objective function."

23 The target for the output gap and the rate of inflation is zero, respectively. 


$$
\begin{aligned}
& \min _{\pi_{t}, y_{t}, q_{t}} E_{t} \sum_{i=0}^{\infty} \beta^{i}\left[y_{t+i}^{2}+\mu \pi_{t+i}^{2}\right] \\
\text { s. t } & \\
\pi_{t}= & \beta E_{t} \pi_{t+1}+\kappa y_{t}+b\left(q_{t}-q_{t-1}\right)-\beta b\left(E_{t} q_{t+1}-q_{t}\right)+u_{t}(9)
\end{aligned}
$$

and

$$
\begin{aligned}
y_{t}=E_{t} y_{t+1}- & a_{1}\left(R_{t}^{f}-E_{t} \pi_{t+1}^{f}+\epsilon_{t}\right)+\left(a_{1}(\gamma-1)-a_{2}\right)\left(E_{t} q_{t+1}-q_{t}\right) \\
& +a_{3}\left(y_{t}^{f}-E_{t} y_{t+1}^{f}\right)+v_{t}
\end{aligned}
$$

The resulting targeting rule under flexible domestic inflation targeting is: ${ }^{24}$

$$
y_{t}+\mu\left[\pi_{t}\left(\kappa+\frac{c_{1}}{c_{2}}\right)-\frac{\beta b}{c_{2}} w_{\pi} q_{t}\right]=0
$$

$$
c_{1}=\beta\left(w_{\pi}-b\left(w_{q}-1\right)\right)+b \quad c_{2}=w_{y}+\left(a_{1}(\gamma-1)-a_{2}\right)\left(w_{q}-1\right)
$$

The open economy target rule is more complex than in the canonical closed-economy New Keynesian model. First, even though it does not appear in the objective function, the real exchange rate appears in the target rule alongside the target variables $\pi_{t}$ and $y_{t}$. This indicates that basing the target rule on the two target variables alone would be suboptimal: the real exchange rate provides essential information. Second, both Phillips curve and IS parameters as well as the discount factor determine the relative weights on the rate of domestic inflation and the real exchange rate. The size of these weights depends in large part on the strength of the (expected) real interest rate and exchange rate channel on the demand side and the sensitivity of domestic inflation to the output gap and changes in the real exchange rate on the supply side. The difference between the target rule in a closed economy and the target rule in an open economy is due to the existence of the exchange rate channel in the Phillips curve. If $b=0$, then $w_{\pi}=0=c_{1}$ and the open-economy target rule reverts to its closed-economy counterpart.

Equation (10) can be combined with the Phillips curve, the IS relation and the UIP condition to generate solutions for the endogenous variables and their variances.

\footnotetext{
24 A step-by-step derivation of all target rules and an explanation of the solution technique employed to determine the forward-looking expectations of inflation, output, and the real exchange rate appear in the appendix.
} 


\section{B. Targeting "R(eal)-EX(change)-Rate-Adjusted" Inflation}

As mentioned in the introduction, several contributions to the literature argue that optimal policy in an open economy is isomorphic to policy in a closed economy. In this section attention focuses on the circumstances under which the target rule in a closed and an open economy are virtually the same. Our aim is to show that choosing an alternative target variable for inflation is the mechanism whereby an open-economy target rule can be made to look exactly like its closed-economy counterpart. This alternative target variable is domestic inflation stripped of the effects of changes in the real exchange rate.

The preceding section showed that the existence of a real exchange rate channel in the Phillips curve is instrumental in shaping the target rule for an open economy. Both the current and expected change in the real exchange rate appears on the right-hand side of the Phillips curve, which is shown again for convenience below.

$$
\pi_{t}=\beta E_{t} \pi_{t+1}+\kappa y_{t}+b\left(q_{t}-q_{t-1}\right)-\beta b\left(E_{t} q_{t+1}-q_{t}\right)+u_{t} \text { ? }
$$

The Phillips curve can be rewritten as

$$
\pi_{t}-b\left(q_{t}-q_{t-1}\right)=\beta\left(E_{t} \pi_{t+1}-b\left(E_{t} q_{t+1}-q_{t}\right)\right)+\kappa y_{t}+u_{t}
$$

Defining

$$
\pi_{t}^{R E X}=\pi_{t}-b\left(q_{t}-q_{t-1}\right)
$$

as the domestic rate of inflation purged of the real exchange rate effect allows us to rewrite the original open-economy Phillips curve as

$$
\pi_{t}^{R E X}=\beta E_{t} \pi_{t+1}^{R E X}+\kappa y_{t}+u_{t}
$$

Written in this form, equation (12) looks like the original Phillips curve. The only difference between equation (4) and equation (12) pertains to the definition of the rate inflation.

The remaining two equations of the model can be rewritten in terms of the real-exchangerate-adjusted rate of inflation:

$$
\begin{aligned}
& y_{t}=E_{t} y_{t+1}-a_{1}\left(R_{t}-E_{t} \pi_{t+1}^{R E X}\right)+\left(a_{1}(b+\gamma)-a_{2}\right)\left(E_{t} q_{t+1}-q_{t}\right)+a_{3}\left(y_{t}^{f}-E_{t} y_{t+1}^{f}\right)+v_{t} \\
& R_{t}-E_{t} \pi_{t+1}^{R E X}=R_{t}^{f}-E_{t} \pi_{t+1}^{f}+(1+b)\left(E_{t} q_{t+1}-q_{t}\right)+\varepsilon_{t}
\end{aligned}
$$

The last required change involves modifying the objective function of the policymaker. The target variable for inflation is now the real-exchange-rate-adjusted rate of inflation. 
After substitution of equation (14) into equation (13) to eliminate the real exchange rate, the optimization problem of the policymaker can be stated as:

$$
\begin{gathered}
\min _{y_{t}, \pi_{t}^{R E X}, R_{t}} \frac{1}{2} E_{t}\left[\sum_{i=0}^{\infty} \beta^{i}\left[y_{t+i}^{2}+\mu \pi_{t+i}^{R E X}\right]\right] \\
\text { s. t. } \\
\pi_{t}^{R E X}=\beta E_{t} \pi_{t+1}^{R E X}+\kappa y_{t}+u_{t} \\
\text { and } \\
y_{t}=E_{t} y_{t+1}-a_{1}\left(R_{t}-E_{t} \pi_{t+1}^{R E X}\right)+\frac{\left(a_{1}(b+\gamma)-a_{2}\right)}{1+b}\left(R_{t}-E_{t} \pi_{t+1}^{R E X}-R_{t}^{f}+E_{t} \pi_{t+1}^{f}-\varepsilon_{t}\right)+a_{3}\left(y_{t}^{f}-E_{t} y_{t+1}^{f}\right)+v_{t}
\end{gathered}
$$

Solving the optimization problem yields the target rule under REX inflation targeting:

$$
y_{t}+\mu \kappa \pi_{t}^{R E X}=0
$$

As in the closed-economy model, only the Phillips curve parameter $\kappa$ appears in the target rule. Demand-side parameters have no role to play. Combining equation (16) with equations (12) - (14) yields the solutions for the endogenous variables and the policy instrument.

\section{Targeting CPI Inflation}

If the focus of policy rests on CPI inflation, then the policymaker minimizes

$$
\frac{1}{2} E_{t}\left[\sum_{i=0}^{\infty} \beta^{i}\left[y_{t+i}^{2}+\mu \pi_{t+i}^{C P I 2}\right]\right]
$$

subject to the constraint which is represented by the model economy. After rewriting the structure of the economy in terms of the CPI inflation rate, we can restate the policy objective as:

$$
\min _{y_{t}, \pi_{t}^{C P I}, q_{t}} \frac{1}{2} E_{t}\left[\sum_{i=0}^{\infty} \beta^{i}\left[y_{t+i}^{2}+\mu \pi_{t+i}^{C P I 2}\right]\right]
$$

subject to

$\pi_{t}^{C P I}=\beta E_{t} \pi_{t+1}^{C P I}+\kappa y_{t}+(1+\beta)(\gamma+b) q_{t}-(\gamma+b) q_{t-1}-\beta(\gamma+b) E_{t} q_{t+1}+u_{t}$

and

$$
y_{t}=E_{t} y_{t+1}-a_{1}\left(R_{t}^{f}-E_{t} \pi_{t+1}^{f}+\varepsilon_{t}\right)-\left(a_{1}(1-\gamma)+a_{2}\right)\left(E_{t} q_{t+1}-q_{t}\right)+a_{3}\left(y_{t}^{f}-E_{t} y_{t+1}^{f}\right)+v_{t}
$$

Combining the first-order conditions of the optimization problem leads to the following target rule: 


$$
\begin{gathered}
y_{t}+\mu\left[\left(\kappa+\frac{f_{1}}{f_{2}}\right) \pi_{t}^{C P I}-\frac{\beta(\gamma+b) \phi_{\pi}}{f_{2}} q_{t}\right]=0 \\
f_{1}=\beta \phi_{\pi}+(\gamma+b)\left(1+\beta\left(1-\phi_{q}\right)\right) \quad f_{2}=\phi_{y}-\left(a_{1}(1-\gamma)+a_{2}\right)\left(\phi_{q}-1\right)
\end{gathered}
$$

As with the target rule under domestic inflation targeting, the real exchange rate appears in the target rule in addition to the target variables proper. Again, the level of the real exchange rate provides essential information that is contained neither in the rate of CPI inflation nor the output gap. Although the target rule under CPI inflation targeting looks similar to the target rule under domestic inflation targeting, there is one fundamental difference between the two rules. Even if the real exchange rate channel in the Phillips curve is shut off, i.e. $b=0$, the target rule under CPI inflation targeting does not revert to the target rule under domestic inflation targeting, which is identical to the closed-economy targeting rule in the canonical New Keynesian model. Setting $b=0$ results neither in $f_{1}=0$ nor in reducing the coefficient on the real exchanger rate to zero. The relative weight on the CPI inflation rate and the real exchange rate, respectively, merely decreases in size and the target rule simplifies to

$$
y_{t}+\mu\left[\left(\kappa+\frac{f_{1}}{f_{2}}\right) \pi_{t}^{C P I}-\frac{\beta \gamma \phi_{\pi}}{f_{2}} q_{t}\right]=0
$$

where $f_{1}=\beta \phi_{\pi}+\gamma\left(1+\beta\left(1-\phi_{q}\right)\right)$.

By definition, the CPI inflation rate depends in part on the degree of openness multiplied by a change in the real exchange rate. Thus, if the policymaker changes the policy instrument in response to an IS shock, the real exchange rate changes, which in turn filters through to the $\mathrm{CPI}$ inflation rate. Attempting to prevent the output gap from changing does not work in the present case because the rate of CPI inflation is directly affected by changes in the real exchange rate.

Solutions for the endogenous variables and the policy instrument and their variances can be obtained by combining equation (20) with equations (18) and (19).

\section{Assessing the Performance of the Flexible Inflation Targeting Strategies}

The previous section establishes that, depending on the choice of an inflation objective, optimal monetary policy in an open economy can but need not be isomorphic to that of a closed economy. While informative, the isomorphism result by itself says very little about the 
relative merits of flexible domestic, CPI, and REX inflation targeting. This section therefore carries out two tests to evaluate the performance of the three monetary policy strategies. The first test assesses the role of a central bank's innate aversion to inflation variability in ranking the flexible inflation targeting regimes by loss score. It further compares the variability of the output gap across the different inflation targeting regimes and examines the extent to which a particular choice for the inflation objective achieves price stability across the board. ${ }^{25}$ Consideration is also given to the behavior of the real exchange rate and the policy instrument. The second test assesses the inflation-output gap tradeoffs under each of the three flexible inflation targeting regimes. Prior to these assessments we examine the target rules underlying the three inflation targeting strategies. A comparison of the target rules allows us to make conjectures about the extent to which the output gap and the real exchange rate fluctuate across the flexible inflation targeting regimes, conjectures that receive strong support in the numerical assessments that follow.

\section{A. The Three Target Rules}

Table $1 A$ presents the target rule for each of the three strategies. Consider the weights the central bank attaches to the inflation rate and the real exchange rate relative to the output gap under domestic and CPI inflation targeting. The coefficients $c_{1}, c_{2}, f_{1}$, and $f_{2}$ play an important role in determining the size of these weights. The four coefficients describe the potency of the monetary transmission channels in the Phillips curve $\left(c_{1}, f_{1}\right)$ and the IS relation $\left(c_{2}, f_{2}\right)$ under the two monetary policy strategies.

Both consumption openness $(\gamma)$ and supply-side openness $(b)$ matter for the size of $f_{1}$ while only the latter directly affects the size of $c_{1}$. As a result $f_{1}>c_{1}$ : the real exchange rate channel in the Phillips curve is more potent under CPI than under domestic inflation targeting. At the same time it turns out that $f_{2}=c_{2}$, which suggests that the choice of inflation objective has no implications for the strength of the monetary transmission channels on the demand side. ${ }^{26}$

25 Arguably, price stability goes beyond keeping a given measure of inflation low and stable. In New Zealand, for instance, price stability is defined not solely in terms of CPI inflation but is measured in terms of changes in the general level of prices. This clearly indicates that changes in other price indices figure in the overall assessment of flexible CPI inflation targeting (Monetary Policy and the New Zealand Financial System (1992), p. 35).

26 These results are established with the help of solving the models numerically. The numerical solutions establish, for instance, that $\left|\phi_{\pi}\right|>\left|w_{\pi}\right|$. The effect of the current real exchange rate on expected CPI inflation is greater than on expected domestic inflation. More details on the numerical solution procedure are given in the appendix. 
With $f_{1}>c_{1}$ the relative weight on inflation under CPI inflation targeting is greater than the relative weight on inflation under domestic inflation targeting. Also, the relative weight on the real exchange rate in the CPI inflation target rule is greater than its counterpart in the domestic inflation target rule. This is because the numerator of the coefficient on $q_{t}$ is greater in the CPI inflation target rule than in the domestic inflation target rule.

In general, the size of the relative weight on inflation and the real exchange rate in the respective target rule reflects the importance of these two variables vis-à-vis the output gap in the setting of policy under the three regimes.

In the case of flexible inflation targeting where both the inflation and the output gap objective are deemed important or non-negligible, the size of the relative weights in the target rules should convey information about the variability of those variables that explicitly or implicitly figure in all three target rules. ${ }^{27}$ These variables are the output gap and the real exchange rate. According to Table $1 A$, the relative weights on inflation and the real exchange rate are largest under CPI inflation targeting but smallest under REX inflation targeting. This suggests the following conjectures:

\section{Conjecture 1:}

The output gap is most stable under REX inflation targeting.

\section{Conjecture 2:}

fluctuations in the real exchange rate should be lowest under CPI inflation targeting but most pronounced under REX inflation targeting where the relative weight on the real exchange rate is zero.

To assess the plausibility of these conjectures, we use a numerical solution procedure with the following plausible parameter values: $a_{1}=0.45, a_{2}=0.195, a_{3}=0.27, b=$ $0.1, \kappa=0.1, \beta=1$. The choice of parameter values is explained in the note below Table 1 . For the computation of the variances of endogenous variables in Section $B$ we assume that all disturbances are independent white noise processes with unit variance.

Using the above parameter values, we calculate the relative weights on the respective rate of inflation and the real exchange rate in the three target rules. These relative weights appear in Table $1 B$. Each horizontal line is based on a different value of the relative inflation aversion parameter $\mu$. The entries confirm that the relative weight on inflation is largest under CPI inflation targeting and smallest under REX inflation targeting. A distinctive feature of flexible CPI inflation targeting is that the relative weight the central bank attaches to the CPI

27 To give precise meaning to the concept of "importance", we let $\mu$ take on values 1,4 , and 8 . 
inflation rate in the target rule roughly corresponds to its relative aversion to inflation variability in the objective function. Also, under flexible CPI inflation targeting, the relative weight on the real exchange rate is considerably higher than under domestic inflation targeting.

B. Relative Rankings and the Variability of the Model Variables Across the Three Regimes ${ }^{28}$

The results of the comparison of the three targeting strategies under discretion are presented in Tables 2,3, and 4. Table 2 shows the results for the case when the policymaker is equally concerned about inflation variability and output gap variability $(\mu=1)$ while Tables 3 and 4 report the results for the case where the policymaker's concern about inflation variability increasingly outweighs the concern about output gap variability, i.e. $\mu=4$ and $\mu=8$, respectively.

Let us begin by considering the information contained in section A of Tables 2 and 3 . The loss scores for the three inflation targeting regimes appear in bold-face as diagonal entries. Off-diagonal entries show how losses change if the variance of one of the two alternative measures of inflation takes the place of the variance of the inflation rate being targeted in the loss function. Inspection of the diagonal elements of the two tables reveals a striking contrast. The ranking of the three inflation targeting strategies by loss score is reversed as the central bank's emphasis shifts from equal concern about inflation and output gap variability towards greater concern about inflation stability. Placing greater emphasis on inflation stability clearly favors CPI targeting over domestic and particularly REX inflation targeting which dominates the other two strategies for $\mu=1$. Losses under CPI inflation targeting are also fairly compact but far less so for domestic and REX inflation targeting as the variance of CPI inflation increases markedly under both regimes.

A second noteworthy result is that a CPI inflation target produces not only the lowest variance of the three inflation measures ${ }^{29}$ but also stable inflation rates across the board. The variances of all three measures of inflation are lower under CPI inflation targeting than either domestic inflation or REX inflation targeting. Indeed the variance of REX inflation is even smaller than the variance of CPI inflation itself if $\mu=1$ and the central bank chooses a CPI inflation objective; the variability of domestic inflation is only slightly above that of CPI

28 This test consists of reading the information in part B of Tables 2 - 4 horizontally whereas the inflationoutput tradeoffs (discussed in Section $C$ ) are based on a vertical reading of the column entries of Tables $2 B$ $(\mu=1)$, Table $3 B(\mu=4)$, and Table $4 B(\mu=8)$. The output gap and the rates of inflation are measured at the same frequency.

29 Compare the diagonal entries in boldface in Section B of Tables 2 and 3. 
inflation. In marked contrast, domestic inflation targeting and especially REX inflation targeting result in substantial variability of CPI inflation. Putting greater emphasis on inflation control in the objective function $(\mu=4)$ leads to a massive drop in the variance of CPI inflation under CPI inflation targeting - more than threefold- but only moderate (domestic inflation targeting) or slight (REX inflation) decreases of inflation variability under the alternative targeting strategies.

CPI inflation targeting has one distinct drawback. It leads to pronounced fluctuations in the output gap compared to the other two inflation targeting strategies. This is evidenced by the extremely low variability of the output gap under domestic inflation targeting (0.064) and particularly under REX inflation targeting (0.0098) relative to CPI inflation targeting (0.6149) in the case where $\mu=1$ (Confirmation of conjecture 1 ). With a relatively low relative weight on the inflation rate, the central bank's foremost concern lies with the stabilization of the output gap. And here REX inflation targeting has a natural advantage as the output gap (and REX inflation) is sensitive only to cost-push disturbances. Demand-side disturbances can be completely offset by simply manipulating the policy instrument.

Financial stability concerns are an important input in assessing the stance of monetary policy. Central banks wish to avoid contributing to erratic swings in asset prices that have the potential to cause upheaval in financial markets and the wider economy. How do the three inflation targeting regimes affect the variability of the real exchange rate and the policy instrument? Inspection of the lower right half of Tables 2 and 3 confirms conjecture 2: CPI inflation targeting stabilizes the real exchange rate much better than the alternative targeting strategies. CPI inflation targeting also makes for less variation of the nominal interest rate.

The results described above do not change markedly if the central bank places even greater relative emphasis on inflation stability $(\mu=8)$. According to Table 4 , only two minor modifications must be made to our assessment of the targeting strategies. Both changes concern the relative standing of domestic inflation targeting: of the three strategies it is now best at controlling the variability of domestic inflation but worst at managing the variability of the real exchange rate. As a final note, we observe that overriding concern with inflation stability leads a central bank to achieve zero inflation variability only under CPI inflation targeting. 


\section{Policy Frontiers and Inflation-Output Variability Tradeoffs}

Additional evidence on the performance of the three flexible inflation targeting strategies can be gleaned by considering the shape and location of policy frontiers which describe the inflation-output variability tradeoffs under each regime. Figure 1 shows the policy frontiers under CPI inflation, domestic, and REX inflation targeting. ${ }^{30}$

It is immediately apparent that the three targeting strategies produce vastly different inflation-output variability tradeoffs. In Figure $1 C$, under REX inflation targeting, the inflation-output variability tradeoffs are very compact. There is not much variation in fluctuations of the output gap and the rate of inflation (no matter how inflation is measured). There are, however, dramatic differences in the loci of the variability tradeoffs. The policy frontier along which CPI inflation variability is traded off for output gap variability under REX inflation targeting is a considerable distance to the right of (and hence inferior to) the policy frontiers that govern the tradeoff between output gap and REX inflation variability and the tradeoff between output gap and domestic inflation variability. Figures $1 A$ and $I B$ illustrate that CPI inflation and especially domestic inflation targeting give rise to far wider inflation-output variability tradeoffs. These observations admit a simple interpretation: the central bank's relative aversion to inflation variability is of less consequence for the variability of the output gap and all three measures of inflation if it targets REX inflation instead of domestic or CPI inflation.

In two of the three cases considered the inflation rate targeted traces out the most preferred policy frontier, i.e. the one closest to the origin. Figure $1 A$ depicts the three policy frontiers under CPI targeting. The one which describes the tradeoff between the variability of CPI inflation and the output gap lies to the left of those based on REX or domestic inflation. In Figure $1 B$ we find a similar result: under domestic inflation targeting, the tradeoff between domestic inflation variability and output gap variability occurs to the left of the policy frontiers based on REX inflation or CPI inflation. Figure $1 C$ illustrates a contrary example. When price stability is of great or medium concern, REX inflation targeting produces a variability tradeoff between itself and the output gap that lies above the variability tradeoff between domestic inflation and the output gap.

A comparison of the three figures also reveals an interesting pattern between CPI inflation and output gap variability under the three strategies. The segment along the lower part of the three policy frontiers (between $\mu=1$ and $\mu=4$ ) is flatter which implies that the 
tradeoff between CPI inflation and output gap variability is more favorable than the variability tradeoff between domestic / REX inflation and the output gap when the central bank does not care overly about inflation stability.

Figure $1 D$ summarizes the behavior of the real exchange rate and the policy instrument under the three targeting strategies. In general, greater emphasis on inflation stability leads to greater variability in both the real exchange rate and the policy instrument. But there are subtle differences in the way the variances of these two variables evolve as the focus of policy shifts more towards keeping inflation in check. For instance, under CPI inflation targeting greater emphasis on inflation stability translates into much larger fluctuations in the real exchange rate compared to the policy instrument. The variability of the real exchange rate also increases faster than the variability of the policy instrument under domestic inflation targeting. Just the opposite is the case, however, under REX inflation targeting. Under this targeting regime, fluctuations in the policy instrument increase faster than fluctuations in the real exchange rate as the emphasis on price stability increases.

\section{A Throw-Back to Poole: How Sensitive is the Ranking to the Sources of Shocks?}

A central result of Clarida, Gali and Gertler's (1999) analysis of monetary policy in the closed economy is that "The optimal policy calls for adjusting the interest rate to perfectly offset demand shocks ....Demand shocks do not force a short-run trade-off between output and inflation." In general, this result does not carry over to the type of open-economy model considered here. Thus considerations such as Poole (1970) dealt with where the ranking of alternative policies depends on the relative variability of the shocks faced by the policy maker become relevant.

The stabilizing properties of monetary policy in the current framework depend on the measure of inflation targeted. Under domestic inflation or CPI targeting the policymaker confronted with demand-side shocks faces a tradeoff between stabilizing inflation and the output gap. The isomorphism between optimal monetary policy in the open and closed economy breaks down. REX inflation targeting restores the isomorphism. The Clarida, Gali and Gertler (1999) result holds under this targeting procedure.

To see how the origin and variability of shocks affects the ranking of the three targeting procedures, we modify the original set-up by increasing the variance of each demand-side disturbance from one to four while the variance of the cost-push shock is kept at one. Table 5 presents the findings with this modification when the central bank is equally 
concerned about inflation and output gap variability $(\mu=1)$. Table 6 shows findings for substantially greater aversion to inflation variability $(\mu=8)$.

First, compare the loss scores in the top panels of Tables 5 and 6 to those in Tables 2 and 4. From a loss minimizing perspective, a central bank with a relatively low aversion to inflation variability $(\mu=1)$ does best under REX inflation targeting. The advantage of this strategy increases if shocks to the demand side of the economy are far more variable than the cost-push shock (Table 5 compared to Table 2). As the demand-side shocks become more variable, the loss score for REX inflation targeting is unchanged while the loss score for the other two strategies rises. Comparison of Tables 4 and 6 shows, however, that a highly inflation-averse central bank $(\mu=8)$ would still choose CPI inflation targeting with highly variable demand-side shocks albeit by a smaller margin.

Thus, as expected, more variability of demand-side shocks favors REX inflation targeting; under this strategy these shocks are perfectly offset by adjusting the interest rate. $\mathrm{CPI}$ inflation targeting is still attractive as can be seen from the rankings of the three strategies if performance is measured by minimizing the variances of each of the inflation measures we consider. Moreover, while the variance of the real exchange rate and nominal interest rate increase for all strategies as demand shocks become more variable, CPI inflation targeting still produces the lowest variance for both. These results hold for either $\mu=1$ or $\mu=8$.

Under REX inflation targeting, the variances of REX inflation and the output gap are not affected by the increase in the size of the demand-side variances. Thus, as far as the stabilization of REX inflation and the output gap is concerned, the performance of CPI inflation relative to REX inflation targeting worsens. This fact helps explain why, from a loss-minimizing point of view, the performance of CPI inflation targeting deteriorates markedly.

To summarize, an increase in the variability of demand-side shocks relative to costpush shocks increases the desirability of REX inflation targeting relative to the other two strategies. Even so, CPI inflation targeting retains its advantage in providing low inflation variability by all measures and results in lower variability of the real exchange rate and policy instrument. The advantage of CPI inflation targeting in producing relatively low inflation variability makes this strategy optimal for the highly inflation-averse policymaker, even in an environment of predominant demand-side shocks (Table 6). 


\section{Discretion versus Policy from a Timeless Perspective}

So far we have considered only policy under discretion. Papers such as Clarida, Gali and Gertler (1999) or Woodford (1999a, 2003) show that in the closed-economy canonical New Keynesian model policy under discretion results in a stabilization bias. Policy under commitment from what Woodford $(1999 \mathrm{a}, \mathrm{b})$ terms the timeless perspective is welfare improving. How does considering policy from a timeless perspective affect the choice of an inflation objective?

In our open-economy framework, results under this form of commitment appear in Table 7, for the case where $\mu=4$, which can be directly compared to Table 3 . The relative ranking of the three strategies on the basis of the loss score is unchanged from that under discretion.

As expected, the output gap is more variable under policy from a timeless perspective than under discretion. The reverse holds for all three definitions of inflation: inflation is less variable under policy from a timeless perspective than discretion. Moreover, all three flexible inflation targeting regimes produce smaller fluctuations of the nominal interest rate under policy from a timeless perspective than discretion. The expectations channel of monetary policy is more potent under commitment than discretion, leading the central bank to use its instrument less aggressively. Real exchange rate variability increases under policy from a timeless perspective as the gain of greater inflation and instrument stability is moderated by a somewhat greater burden on the real exchange rate to adjust.

The welfare gains of commitment relative to discretion are shown in the top righthand panel of Table 7. These gains are largest under REX inflation targeting, amounting to almost 15 percent. Under domestic inflation targeting the welfare gain is almost 14 percent. In contrast the benefits associated with policy from a timeless perspective relative to discretion are less than 8 percent under CPI inflation targeting. ${ }^{31}$

The stabilization bias is most pronounced under discretionary REX inflation targeting because this strategy assigns a rather large weight to the output gap in the target rule. Consequently, the gains from moving from discretion to commitment are greatest under REX inflation targeting which is akin to carrying out policy in a closed economy. Under domestic or CPI inflation targeting the weight on the output gap in the target rule is smaller, leading to a smaller stabilization bias and hence smaller welfare gains under commitment.

31 Results have also been computed for the case where the central bank's relative aversion to inflation variability is lower $(\mu=1)$. In this case the welfare gains from commitment are smaller, ranging from 9.09 percent under REX targeting to 4.55 percent under CPI targeting. It is again the case that the relative ranking of the strategies by loss score is unchanged from that under discretion 
Notwithstanding the differential welfare gains, consideration of policy from a timeless perspective does not affect the ranking of alternative inflation targeting regimes derived under discretion.

\section{Conclusion}

This paper considers the choice of an inflation objective in a New Keynesian open economy model which has a direct exchange rate channel in the Phillips curve. In the model this channel results from the fact that producers care about the real exchange rate in setting prices. There are other rationales for such a real exchange rate channel in models such as those of Ball (1999), Svensson (2000) and Froyen and Guender (2007). With a direct exchange rate channel in the Phillips curve the transmission mechanism of monetary policy is no longer required to work exclusively through the output gap. Instead it relies as well on the real exchange rate to bring about changes in the rate of inflation.

A more expansive transmission mechanism affects the way that an optimizing central bank sets policy. If the CPI or domestic rate of inflation is the inflation objective, the current framework has policy implications that differ sharply from models such as those of Clarida, Gali and Gertler (2001, 2002) and Gali and Monacelli (2005) which do not provide for a direct exchange rate channel in the Phillips curve. In their open-economy models optimal monetary policy is isomorphic to that in the closed economy counterpart. With a direct exchange rate channel, the isomorphism breaks down. The difference in optimal policies is most easily seen in the specification of the target rules (Table 1 ). With a direct exchange rate channel in the Phillips curve, the real exchange rate appears as an essential element in the target rule. In addition, characteristics of the demand-side of the economy influence the relative weights the central bank places on the components of the target rule. Demand-side disturbances can no longer be offset by a mere adjustment of the policy instrument; the response to all disturbances depends on the central bank's relative aversion to inflation variability.

We consider a real-exchange-rate-adjusted (REX) inflation targeting regime that restores the isomorphism with policy in a closed economy. This closes down the real exchange rate channel in the (redefined) Phillips curve. The resulting target rule contains only REX inflation and the output gap. Its parameters do not depend on characteristics of the demand-side of the model and demand-side disturbances can again be offset without cost by adjustments in the policy instrument. 
So what to aim for? With CPI or domestic inflation as the inflation objective, the real exchange rate channel enhances the inflation-output tradeoff. The effect of the exchange rate on the inflation rate in the Phillips curve complements the indirect effect through the output gap as the policymaker adjusts the interest rate. This is more pronounced for CPI inflation than domestic inflation because import prices are included in the CPI. Thus we find that a higher degree of aversion to inflation variability in general favors CPI inflation targeting (See Tables 4 and 6.) CPI inflation targeting also produces the lowest variability of the real exchange rate.

The weaknesses of REX inflation targeting are also its strength. Among the three strategies REX inflation targeting gives the highest weight to the output gap in the target rule for a given inflation aversion. For all cases we consider, this results in REX inflation targeting producing the lowest variability of the output gap, often by a large margin. For a central bank with a relatively high weight on the output gap in the loss function (Tables 2 and 5), REX inflation targeting performs best as long as REX inflation is the preferred aggregate.

In countries such as New Zealand and the United Kingdom where the central bank's agreement with the government stipulates that monetary policy be implemented with price stability as the primary goal, CPI inflation targeting is likely to be dominant. It is only a slight exaggeration to say that the central bank should aim for CPI inflation regardless of which inflation measure it cares about. CPI inflation targeting provides low variability of all three inflation measures, often the lowest for all three. 


\section{References:}

Allsopp, C., Kara, A., and Nelson, E. (2006). "United Kingdom Inflation Targeting and the Exchange Rate," Economic Journal, vol. 116, F232-F244.

Aoki, K. (2001). “Optimal Monetary Responses to Relative Price Changes,” Journal of Monetary Economics, 48, 55-80.

Ball, L. (1999). “Policy Rules for Open Economies,” In: Taylor J. B. (Ed.): Monetary Policy Rules, The University of Chicago Press, Chicago, 129-156.

Benigno, G., and Benigno P. (2006). "Designing Targeting Rules for International Monetary Policy Cooperation," Journal of Monetary Economics, vol. 53, 473-506.

Blanchard, O., Dell'Aricia G., and Mauro, P. (2010). "Rethinking Macroeconomic Policy," Journal of Money, Credit, and Banking, vol. 42, s1, 199-215.

Bodenstein, M., Erceg, C., and Guerrieri, L. (2008). “Optimal Monetary Policy with Distinct Core and Headline Inflation Rates," Journal of Monetary Economics, vol. 55, S18S33.

Bodenstein, M., Guerrieri, L., and Kilian L. (2012). "Monetary Responses to Oil Price Fluctuations," unpublished manuscript, University of Michigan.

Bunn, P. and Ellis C. (2012a). "How Do Individual UK Producer Prices Behave?" Economic Journal, vol. 122, F16-F34.

Bunn, P. and Ellis C. (2012b). "Examining the Behavior of Individual UK Consumer Prices," Economic Journal, vol. 122, F35-F55.

Clarida, R., Gali, J., and Gertler, M. (1999). 'The Science of Monetary Policy: a New Keynesian Perspective,' Journal of Economic Literature, vol. 37, 1661-1707. Clarida, R., Gali, J., and Gertler, M. (2001). 'Optimal Monetary Policy in Open vs. Closed Economies: An Integrated Approach,' American Economic Review, vol. 91, 248-252.

Clarida, R., Gali, J., and Gertler, M. (2002). 'A Simple Framework for International Monetary Policy Analysis,' Journal of Monetary Economics, vol. 49, 879-904.

Corsetti, G., Dedola, L. and Leduc, S. (2011). "Optimal Monetary Policy in Open Economies," in: Benjamin M. Friedman \& Michael Woodford (ed.), Handbook of Monetary Economics, edition 1, vol. 3, chapter 16, pages 861-933, Elsevier, Amsterdam.

De Paoli, B. (2009). 'Monetary Policy and Welfare in a Small Open Economy,' Journal of International Economics, vol. 77, 11-22.

Dennis, R. (2001). 'Optimal Policy in Rational Expectations Models: New Solution Algorithms,'mimeo, Federal Reserve Bank of San Francisco. 
Engel, C. (2010). "Currency Misalignments and Optimal Monetary Policy: A Reexamination”, American Economic Review, vol. 101, 2796-2822.

Froyen, R. and A. Guender. (2007). Optimal Monetary Policy under Uncertainty, Edward Elgar, Cheltingham.

Gali, J. and Monacelli, T. (2005). 'Optimal Monetary Policy and Exchange Rate Volatility in a Small Open Economy,' Review of Economic Studies, vol. 72, 707-734.

Greenslade, J. and Parker, M. (2012). "New Insights into Price-Setting Behaviour in the United Kingdom: Introduction and Survey Results," Economic Journal, vol. 122, F1F15.

Guender, A. (2006). "Stabilizing Properties of Discretionary Monetary Policies in a Small Open Economy,” Economic Journal, vol. 116, 309-326.

Kirsanova, T., Leith, C., and Wren-Lewis, S. (2006). "Should Central Banks Target Consumer Prices or the Exchange Rate?” Economic Journal, vol. 116, F208-F231. Monacelli, T. (2005). "Monetary Policy in a Low Pass-Through Environment," Journal of Money, Credit, and Banking, vol. 37 (6), 1047-1066.

Monacelli, T. (2013). "Is Monetary Policy Fundamentally Different in an Open Economy," IMF Economic Review, vol. 61, 6-21.

Parker, M. (2013). "Price-Setting Behaviour in New Zealand,” unpublished manuscript.

Poole, W. (1970). “Optimal Choice of Monetary Policy Instrument in a Simple Stochastic Macro Model," Quarterly Journal of Economics, vol. 84 (2), 197-216.

Reserve Bank of New Zealand. (1992). Monetary Policy and the New Zealand Financial System, $3^{\text {rd }}$ edition, Wellington, New Zealand.

Roberts, J. M. (1995). 'New Keynesian Economics and the Phillips Curve,' Journal of Money, Credit, and Banking, vol. 27, 975-84.

Rotemberg, J. (1982). “Sticky Prices in the United States,” Journal of Political Economy, vol. 90, 1187-1211.

Sims, C. (2012). "Statistical Modeling of Monetary Policy and Its Effects," American Economic Review, vol. 102, 1187-1206.

Svensson, L. (2000). 'Open Economy Inflation Targeting,' Journal of International Economics, vol. 50, 117-53.

Svensson, L. (2011). “Inflation Targeting," in: Benjamin M. Friedman \& Michael Woodford (ed.), Handbook of Monetary Economics, edition 1, vol. 3, chapter 22, 1237-1302, Elsevier, Amsterdam. 
Walsh, C. (2009). “Inflation Targeting: What Have We Learned?” International Finance, vol. 12 (2), 195-233.

Woodford, M. (1999a). "Commentary: How Should Monetary Policy Be Conducted in an Era of Price Stability?" in New Challenges for Monetary Policy: A Symposium Sponsored by the Federal Reserve Bank of Kansas City. Federal Reserve Bank of Kansas City, 277-316.

Woodford, M. (1999b). “Optimal Policy Inertia”, Manchester School, vol. 67 (Supplement), $1-35$.

Woodford, M. (2003). Interest \& Prices, Princeton University Press, Princeton, NJ.

Woodford, M. (2011). “Optimal Monetary Stabilization Policy” in: Benjamin M. Friedman \& Michael Woodford (ed.), Handbook of Monetary Economics, edition 1, vol. 3, chapter 14, 723-828, Elsevier, Amsterdam. 
Table 1: The Target Rules Underlying Domestic, CPI, and REX Inflation Targeting

A. The Target Rules Compared

Rule under Domestic Inflation Targeting

$$
\begin{array}{ll}
y_{t}+\mu\left[\pi_{t}\left(\kappa+\frac{c_{1}}{c_{2}}\right)-\frac{\beta b}{c_{2}} w_{\pi} q_{t}\right]=0 & y_{t}+\mu\left[\left(\kappa+\frac{f_{1}}{f_{2}}\right) \pi_{t}^{C P I}-\frac{\beta(\gamma+b) \phi_{\pi}}{f_{2}} q_{t}\right]=0 \\
\hline c_{1}=\beta\left(w_{\pi}-b\left(w_{q}-1\right)\right)+b>0 & f_{1}=\beta \phi_{\pi}+(\gamma+b)\left(1+\beta\left(1-\phi_{q}\right)\right)>0 \\
c_{2}=w_{y}-\left(a_{1}(\gamma-1)+a_{2}\right)\left(w_{q}-1\right)>0 & f_{2}=\phi_{y}-\left(a_{1}(1-\gamma)+a_{2}\right)\left(\phi_{q}-1\right)>0
\end{array}
$$

\section{Rule under CPI Inflation Targeting}

Rule under REX Inflation Targeting

B. The Relative Weights in the Target Rules Based on Parameter Values: $a_{1}=0.45, a_{2}=0.195, a_{3}=0.27, b=0.1, \kappa=0.1, \beta=1$

\begin{tabular}{|c|c|c|c|c|c|}
\hline & \multicolumn{2}{|c|}{ Domestic Inflation Targeting } & \multicolumn{2}{|c|}{ CPI Inflation Targeting } & \multicolumn{2}{c|}{ REX Inflation Targeting } \\
\hline & $\pi_{t}$ & $q_{t}$ & $\pi_{t}^{C P I}$ & $\pi_{t}^{R E X}$ & 0.195 \\
\hline$\mu=1$ & 0.30 & 0.018 & 0.93 & 0.1 \\
\hline$\mu=4$ & 1.27 & 0.057 & 3.97 & 0.395 & 0.4 \\
\hline$\mu=8$ & 2.65 & 0.089 & 8.28 & 0.464 & 0.8 \\
\hline
\end{tabular}

The parameter values for $a_{1}, a_{2}$, and $a_{3}$ depend on deep parameters such as the elasticity of demand, elasticity of substitution, etc. The deep parameters are taken from Svensson (2000). We are not aware of any reliable empirical estimates of $b$. A conservative value for $b$ is chosen so as to not overemphasize the importance of a real exchange rate channel in the Phillips curve. Empirical estimates of $\kappa$ typically fall within the [0.05, 0.4] range. See also the notes to Table 2. 
Table 2: The Variances of the Endogenous Variables and the Policy Instrument under Different Inflation Targeting Strategies: Policymaker is Equally Concerned about Inflation Variability and Output Gap Variability (Discretion with $\boldsymbol{\mu = 1}$ )

\begin{tabular}{|c|c|c|c|c|c|c|c|}
\hline \multicolumn{8}{|c|}{ A. The Loss Functions } \\
\hline$E(L)$ & $C P I T$ & DOMIT & REXIT & & & & \\
\hline$\mu V\left(\pi^{C P 1}\right)+V(y)$ & 1.32 & 2.13 & 2.67 & & & & \\
\hline$\mu V(\pi)+V(y)$ & 1.38 & 1.02 & 1.07 & & & & \\
\hline$\mu V\left(\pi^{R E X}\right)+V(y)$ & 1.28 & 1.88 & 0.99 & & & & \\
\hline \multicolumn{8}{|c|}{ B. Variances of Endogenous Variables } \\
\hline Target Variables & CPIT & DOMIT & $R E X I T$ & Other Variables & $C P I T$ & DOMIT & REXIT \\
\hline$V(y)$ & 0.6149 & 0.0864 & 0.0098 & $V(q)$ & 2.26 & 5.0416 & 5.7197 \\
\hline$V\left(\pi^{C P I}\right)$ & 0.7073 & 2.0465 & 2.6568 & $V(R)$ & 1.9274 & 4.0915 & 5.0385 \\
\hline$V(\pi)$ & 0.757 & 0.933 & 1.0563 & & & & \\
\hline$V\left(\pi^{R E X}\right)$ & 0.6673 & 0.944 & 0.9803 & & & & \\
\hline
\end{tabular}

Note: i. All disturbances are distributed independently with a mean of zero and unit variance. The parameters of the IS relation are $a_{1}=0.45, a_{2}=0.195, a_{3}=0.27$. The parameters of the Phillips curve are $\beta=1, b=0.1, \kappa=0.1$.

ii. The IS parameters depend on structural parameters: $a_{1}=(1-\gamma) \sigma a_{2}=\gamma\left((1-\gamma) \eta+\gamma^{f} \eta^{f}\right) a_{3}=\gamma \zeta^{f}$

where $\gamma=$ degree of consumption openness $=0.3 \quad \sigma=$ intertemporal elasticity of substitution $=0.64$.

$\eta=$ elasticity of substitution between domestic and foreign $\operatorname{good}=1 \quad \eta^{f}=$ foreign elasticity of substitution between foreign and domestic good $=2$.

$\gamma^{f}=$ degree of openness of foreign economy $=0.15 \quad \zeta^{f}=$ share of foreign consumption in foreign output $=0.9$.

Most deep parameters are the same as employed by Svensson (2000). For further details, see Guender (2006).

iii. The numerical results are based on an adapted GAUSS algorithm originally developed by Dennis (2001). Under domestic and CPI inflation targeting, the

numerical solution procedure experienced problems achieving convergence. This problem is often encountered in the literature and is typically solved by adding an interest smoothing term to the objective function (See Svensson (2000). To achieve convergence, we instead adjusted by a factor of 0.005 two terms under domestic inflation and CPI inflation targeting, respectively: $\beta b=0.095$ instead of 0.1 and $2(b+\gamma)=0.795$ instead of 0.8 .

iv. $C P I T=$ CPI Inflation Targeting, DOMIT = Domestic Inflation Targeting, REXIT = Real-Exchange-Rate-Adjusted Inflation Targeting. 
Table 3: The Variances of the Endogenous Variables and the Policy Instrument under Different Inflation Targeting Strategies: Policymaker is More Concerned about Inflation Variability and Output Gap Variability (Discretion with $\boldsymbol{\mu}=\mathbf{4}$ )

\begin{tabular}{|c|c|c|c|c|c|c|c|}
\hline \multicolumn{8}{|c|}{ A. The Loss Functions } \\
\hline$E(L)$ & CPIT & DOMIT & REXIT & & & & \\
\hline$\mu V\left(\pi^{C P 1}\right)+V(y)$ & 2.29 & 5.54 & 9.53 & & & & \\
\hline$\mu V(\pi)+V(y)$ & 3.67 & 3.23 & 3.77 & & & & \\
\hline$\mu V\left(\pi^{R E X}\right)+V(y)$ & 3.31 & 4.07 & 3.85 & & & & \\
\hline \multicolumn{8}{|c|}{ B. Variances of Endogenous Variables } \\
\hline Target Variables & CPIT & DOMIT & REXIT & Other Variables & $C P I T$ & DOMIT & REXIT \\
\hline$V(y)$ & 1.57 & 0.8416 & 0.1479 & $V(q)$ & 3.1608 & 5.9996 & 6.2508 \\
\hline$V\left(\pi^{C P I}\right)$ & 0.179 & 1.1739 & 2.3447 & $V(R)$ & 2.234 & 4.5738 & 5.681 \\
\hline$V(\pi)$ & 0.5253 & 0.5982 & 0.9045 & & & & \\
\hline$V\left(\pi^{R E X}\right)$ & 0.4346 & 0.8074 & 0.9246 & & & & \\
\hline
\end{tabular}

Notes: see Table 2. 
Table 4: The Variances of the Endogenous Variables and the Policy Instrument under Different Inflation Targeting Strategies: Policymaker is Far More Concerned about Inflation Variability and Output Gap Variability (Discretion with $\boldsymbol{\mu = 8 \text { ) }}$

\begin{tabular}{|c|c|c|c|c|c|c|c|}
\hline \multicolumn{8}{|c|}{ A. The Loss Functions } \\
\hline$E(L)$ & CPIT & DOMIT & REXIT & & & & \\
\hline$\mu V\left(\pi^{C P 1}\right)+V(y)$ & 2.61 & 10.67 & 18.74 & & & & \\
\hline$\mu V(\pi)+V(y)$ & 5.54 & 5.00 & 6.50 & & & & \\
\hline$\mu V\left(\pi^{R E X}\right)+V(y)$ & 5.43 & 7.48 & 7.41 & & & & \\
\hline \multicolumn{8}{|c|}{ B. Variances of Endogenous Variables } \\
\hline Target Variables & CPIT & DOMIT & REXIT & Other Variables & $C P I T$ & DOMIT & REXIT \\
\hline$V(y)$ & 2.066 & 2.0424 & 0.5487 & $V(q)$ & 4.2675 & 9.1445 & 7.7916 \\
\hline$V\left(\pi^{C P I}\right)$ & 0.0678 & 1.0784 & 2.2748 & $V(R)$ & 2.2764 & 6.1642 & 7.5455 \\
\hline$V(\pi)$ & 0.4343 & 0.3699 & 0.7442 & & & & \\
\hline$V\left(\pi^{R E X}\right)$ & 0.4202 & 0.68 & 0.8573 & & & & \\
\hline
\end{tabular}

Notes: see Table 2. 
Table 5: The Variances of the Endogenous Variables and the Policy Instrument under Different Inflation Targeting Strategies: Demand-Side Variances are Four Times as Large as the Variance of Cost-Push Shock (Discretion, $\boldsymbol{\mu}=\mathbf{1}, \boldsymbol{\sigma}_{\boldsymbol{i}}^{2}=\mathbf{4}, \boldsymbol{i}=\boldsymbol{v}, \boldsymbol{\epsilon}, \boldsymbol{r}^{\boldsymbol{f}}, \boldsymbol{y}^{\boldsymbol{f}}, \boldsymbol{\pi}^{f}$ and $\boldsymbol{\sigma}_{\boldsymbol{u}}^{2}=\mathbf{1}$ ).

\begin{tabular}{|c|c|c|c|c|c|c|c|}
\hline \multicolumn{8}{|c|}{ A. The Loss Functions } \\
\hline$E(L)$ & CPIT & DOMIT & REXIT & & & & \\
\hline$\mu V\left(\pi^{C P I}\right)+V(y)$ & 3.42 & $N A$ & $N A$ & & & & \\
\hline$\mu V(\pi)+V(y)$ & $N A$ & 1.32 & NA & & & & \\
\hline$\mu V\left(\pi^{R E X}\right)+V(y)$ & $N A$ & $N A$ & 0.99 & & & & \\
\hline \multicolumn{8}{|c|}{ B. Variances of Endogenous Variables } \\
\hline Target Variables & CPIT & DOMIT & REXIT & Other Variables & CPIT & DOMIT & REXIT \\
\hline$V(y)$ & 1.8893 & 0.1291 & 0.0098 & $V(q)$ & 6.8465 & 19.334 & 22.766 \\
\hline$V\left(\pi^{C P I}\right)$ & 1.5350 & 6.3300 & 8.1116 & $V(R)$ & 6.5663 & 15.467 & 20.018 \\
\hline$V(\pi)$ & 0.7834 & 1.1915 & 1.3972 & & & & \\
\hline$V\left(\pi^{R E X}\right)$ & 0.8123 & 0.9441 & 0.9803 & & & & \\
\hline
\end{tabular}

Notes: The off-diagonal scores in part A of the table have been omitted as they do not provide additional useful information not already contained in Table 2. See also Table 2. 
Table 6: The Variances of the Endogenous Variables and the Policy Instrument under Different Inflation Targeting Strategies: Policymaker is Far More Concerned about Inflation Variability than Output Gap Variability and Variances of Demand-Side Shocks are Fourfold the Variance of Cost-Push Shock (Discretion, $\mu=8, \sigma_{i}^{2}=4, i=v, \epsilon, r^{f}, y^{f}, \pi^{f}$ and $\sigma_{u}^{2}=1$ ).

\begin{tabular}{|c|c|c|c|c|c|c|c|}
\hline \multicolumn{8}{|c|}{ A. The Loss Functions } \\
\hline$E(L)$ & CPIT & DOMIT & REXIT & & & & \\
\hline$\mu V\left(\pi^{C P 1}\right)+V(y)$ & 5.97 & $N A$ & $N A$ & & & & \\
\hline$\mu V(\pi)+V(y)$ & NA & 6.34 & $N A$ & & & & \\
\hline$\mu V\left(\pi^{R E X}\right)+V(y)$ & $N A$ & $N A$ & 7.41 & & & & \\
\hline \multicolumn{8}{|c|}{ B. Variances of Endogenous Variables } \\
\hline Target Variables & CPIT & DOMIT & REXIT & Other Variables & CPIT & DOMIT & REXIT \\
\hline$V(y)$ & 5.1601 & 2.8186 & 0.5487 & $V(q)$ & 5.1372 & 16.0047 & 24.8377 \\
\hline$V\left(\pi^{C P I}\right)$ & 0.1015 & 2.5808 & 7.7295 & $V(R)$ & 7.7441 & 11.3731 & 22.5243 \\
\hline$V(\pi)$ & 0.4379 & 0.4407 & 1.0851 & & & & \\
\hline$V\left(\pi^{R E X}\right)$ & 0.4559 & 0.6833 & 0.8573 & & & & \\
\hline
\end{tabular}

Notes: see Tables 2 and 5. 
Table 7: The Variances of the Endogenous Variables and the Policy Instrument under Different Inflation Targeting Strategies: Policymaker is More Concerned about Inflation Variability than Output Gap Variability (Timeless Perspective with $\boldsymbol{\mu}=\mathbf{4}$ ).

\begin{tabular}{|c|c|c|c|c|c|c|c|}
\hline \multicolumn{8}{|c|}{ A. The Loss Functions } \\
\hline$E(L)$ & CPIT & DOMIT & REXIT & \multicolumn{4}{|c|}{ Welfare Gain from Commitment } \\
\hline$\mu V\left(\pi^{C P 1}\right)+V(y)$ & 2.11 & $N A$ & $N A$ & \multicolumn{4}{|c|}{ CPI Inflation Targeting: $7.86 \%$} \\
\hline$\mu V(\pi)+V(y)$ & $N A$ & 2.78 & $N A$ & \multicolumn{4}{|c|}{ Domestic Inflation Targeting: $13.93 \%$} \\
\hline$\mu V\left(\pi^{R E X}\right)+V(y)$ & $N A$ & $N A$ & 3.28 & \multicolumn{4}{|c|}{ REX Inflation Targeting: $14.81 \%$} \\
\hline \multicolumn{8}{|c|}{ B. Variances of Endogenous Variables } \\
\hline Target Variables & CPIT & DOMIT & REXIT & Other Variables & CPIT & DOMIT & REXIT \\
\hline$V(y)$ & 1.5834 & 0.9051 & 0.3260 & $V(q)$ & 3.4218 & 6.3616 & 6.9353 \\
\hline$V\left(\pi^{C P I}\right)$ & 0.1329 & 0.9785 & 2.1656 & $V(R)$ & 1.947 & 3.3178 & 4.9942 \\
\hline$V(\pi)$ & 0.4788 & 0.4681 & 0.7400 & & & & \\
\hline$V\left(\pi^{R E X}\right)$ & 0.4958 & 0.6593 & 0.7375 & & & & \\
\hline
\end{tabular}

Notes: The off-diagonal scores in part A of the table have been omitted as they do not provide additional useful information not already contained in Table 2 . The welfare gain from commitment under each targeting strategy is calculated as: $100\left(E\left(L_{t}\right)^{D I S}-E\left(L_{t}\right)^{T P}\right) / E\left(L_{t}\right)^{D I S}$. See also Table 2 . 


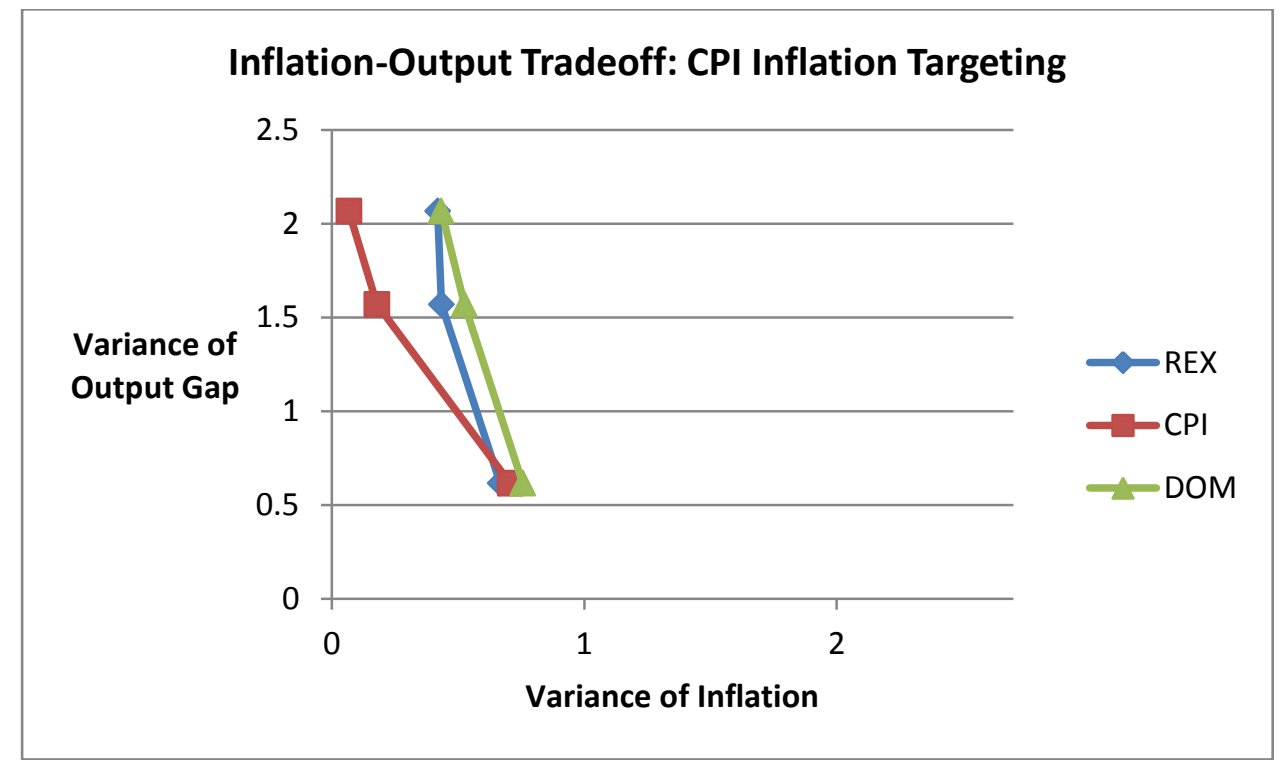

Figure 1A

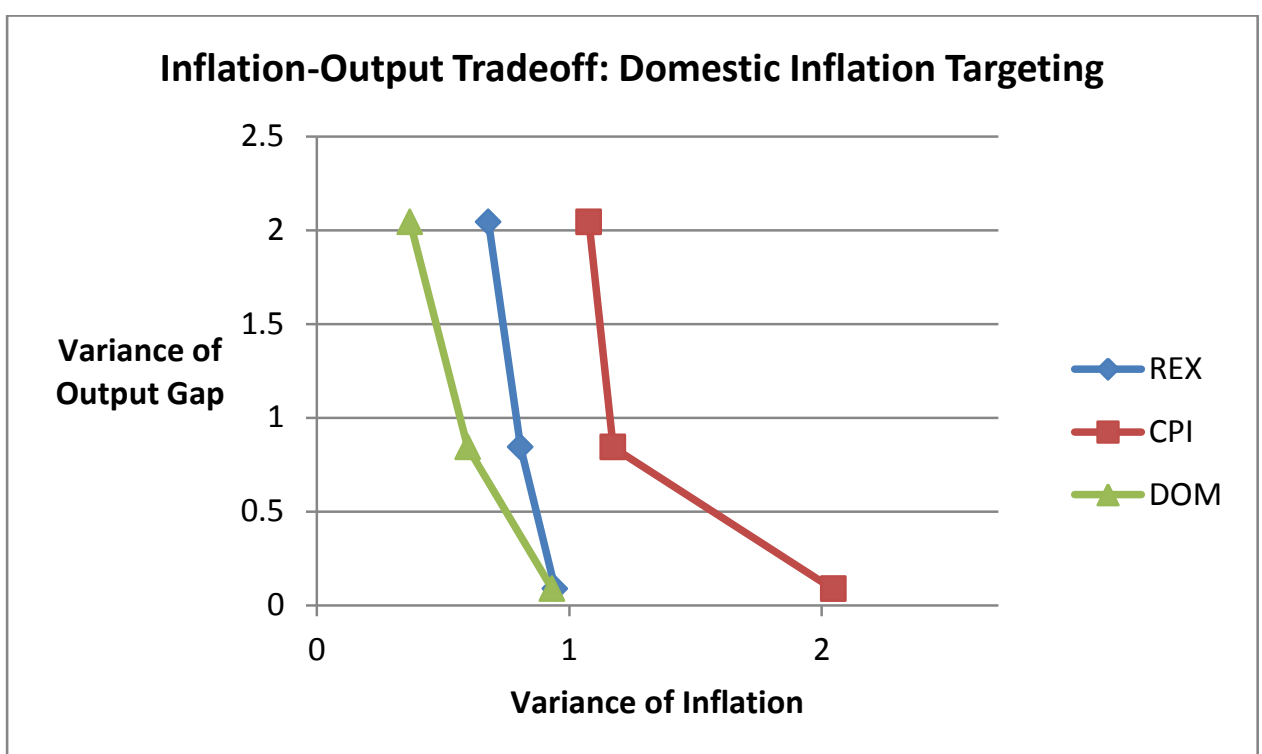

Figure 1B

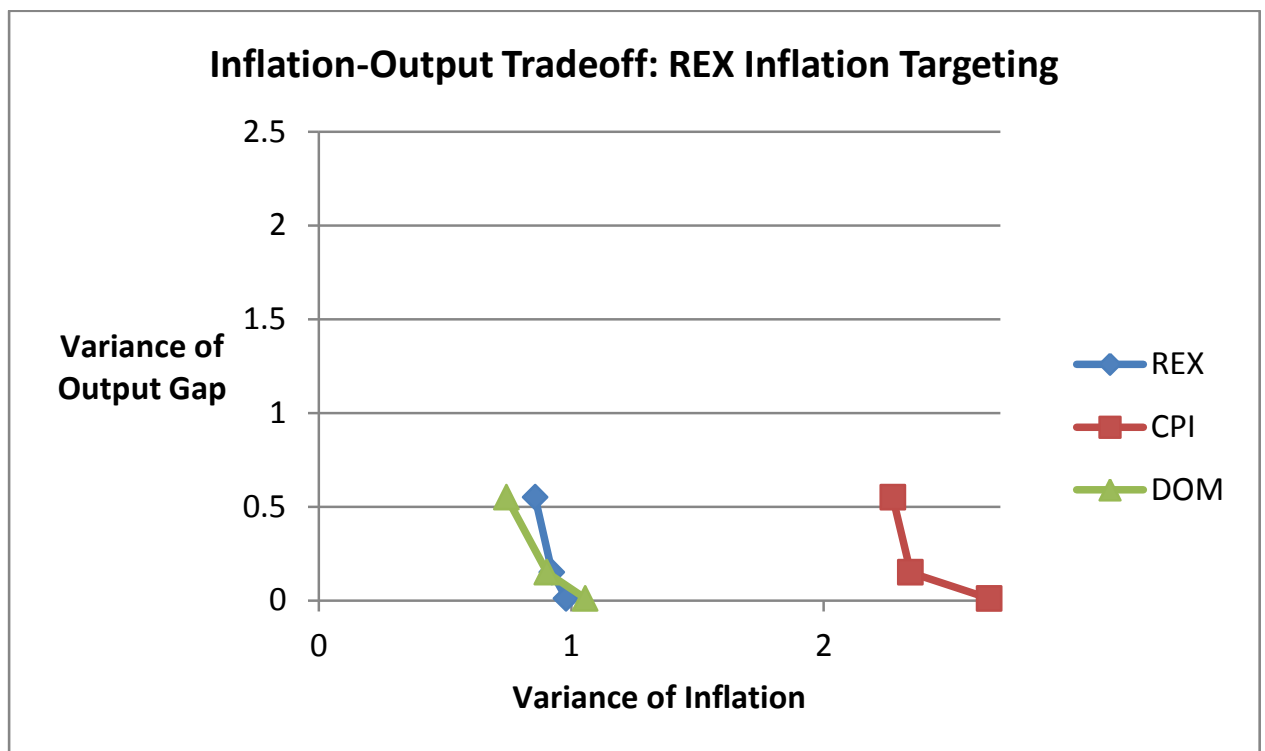

Figure 1C 


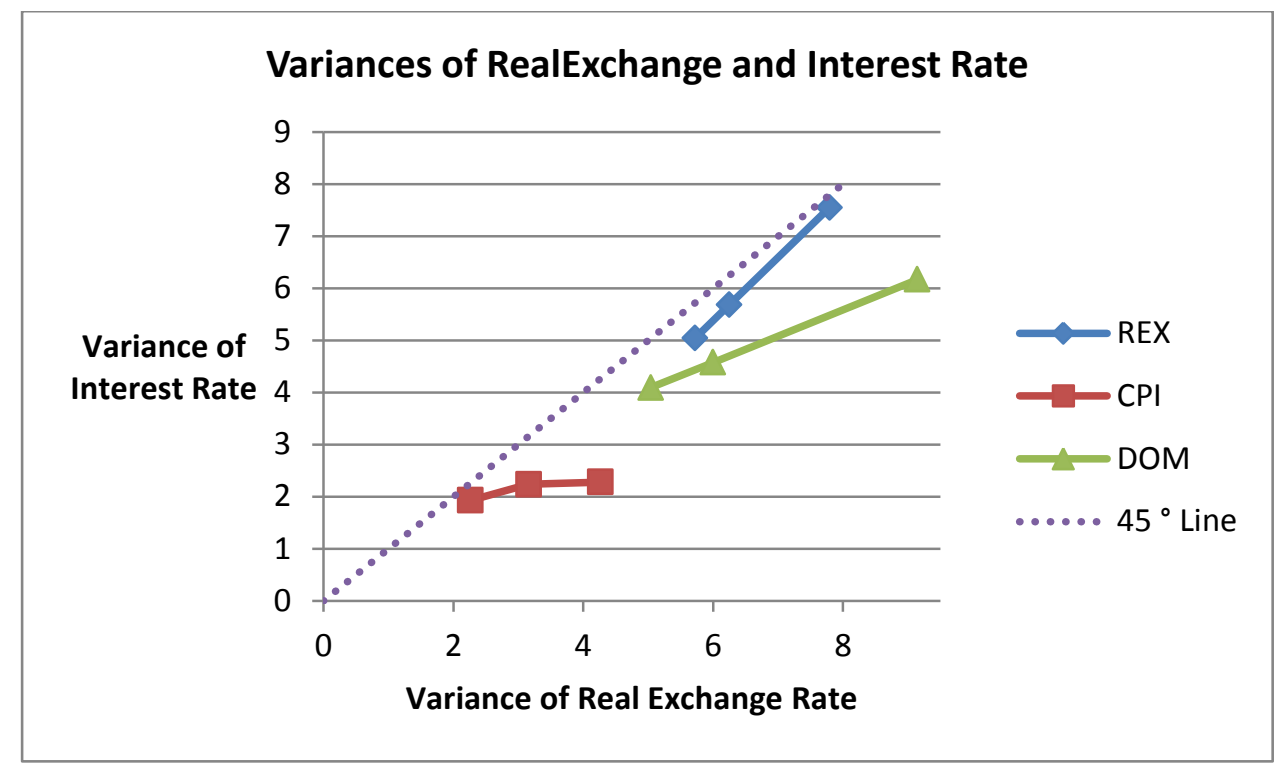

Figure 1D 